\title{
Editorial: o bem-estar humano sob diferentes perspetivas
}

\author{
Editorial: Human well-being from different perspectives
}

Helena Espírito-Santo, PhD (1, 2), Carla Madeira Sério, PsyM (1), Inês Queiroz Garcia, PsyM (1)

(1) Departamento de Investigação \& Desenvolvimento, Instituto Superior Miguel Torga, Coimbra, Portugal

(2) Centro de Investigação do Núcleo de Estudos e Intervenção Cognitivo-Comportamental, Coimbra, Portugal

Autor para correspondência | Corresponding author: Helena Espírito-Santo; Largo de Celas, 1, 3000-132 Coimbra, Portugal; +351910637946; helenum@gmail.com

Em 2018, as editoras da Revista Portuguesa de Investigação Comportamental e Social (RPICS) continuam a privilegiar a publicação de artigos originais de investigação e de revisão nas áreas das Ciências Sociais e do Comportamento.

A RPICS continua a promover o pensamento, questionando as mudanças na sociedade, as suas realidades e repensando as suas problemáticas, promovendo uma reflexão junto do(a)s seus leitore(a)s.

O número 1 do quarto volume da RPICS agrega quatro artigos originais e um artigo de revisão. Ainda que este número da RPICS aborde conteúdos distintos, evidencia-se uma orientação no sentido de estudar variáveis psicológicas positivas e a sua relação com o bem-estar no ser humano, seja ele operacionalizado como saúde física ou mental, estudado no contexto de institucionalização ou no contexto do trabalho, avaliado ao nível da perceção subjetiva de bemestar ou ao nível da conceção da morte com dignidade.

Assim, o primeiro artigo - "Autocompaixão, bem-estar subjetivo e estado de saúde na idade avançada" (Parente, Cunha, Galhardo e Couto) - confirma as evidências de que o estado de saúde físico e mental na idade avançada está associado com a compaixão e com o bem-estar subjetivo. Estes fatores positivos serão elementos chave para um envelhecimento percecionado de forma mais tranquila, e para a adoção de um estilo de coping adaptativo perante as dificuldades que se apresentam na idade avançada. A evidência de que idosos que vivem no seu próprio domicílio apresentam mais compaixão do que os idosos que vivem sob resposta social vem reiterar a importância de se adotarem programas e estratégias ao nível da autocompaixão que promovam uma maior satisfação com a vida, melhor saúde mental e física, especialmente entre idosos institucionalizados.

O segundo artigo - "Percepção de brasileiros sobre a morte digna" (Melo, Bezerra e Lima) - levantou uma questão interessante: qual a conceção dos brasileiros sobre o que é morrer com dignidade e quais as distinções nas diversidades sociodemográficas? Os resultados permitem refletir sobre os procedimentos a desenvolver na assistência a doentes em processo de finitude e aos seus familiares, e mostrando que a preocupação ultrapassa a comunidade médica estando generalizada na sociedade. Na verdade, o que está em causa é a reflexão sobre a morte e a sua remoção do contexto hospitalar.

Outro domínio que merece reflexão diz respeito ao bem-estar entre aqueles que exercem ativamente uma profissão, em concreto a profissão de docente do ensino universitário. Os autores do estudo "Avaliação de fatores de risco psicossociais: estudo com docentes do ensino superior" (Borges, Santos, Saraiva e Pocinho) mostraram que os professores universitários vivem situações de risco psicossocial, especialmente os professores do ensino público, do sexo feminino e mais velhos. A sua descoberta estimulou os autores a sublinhar a importância da intervenção primária, mas também da intervenção secundária e terciária nas instituições universitárias.

Nesta ronda de artigos originais, termina-se como se começou voltando a focar-se no bem-estar na idade avançada, especialmente entre idosos institucionalizados. No estudo "Validação da versão portuguesa do Spiritual WellBeing Questionnaire para a população idosa institucionalizada", Neves, Garcia, Espírito-Santo e Lemos procuraram contribuir para a análise das qualidades psicométricas e validação de um instrumento de medição do bem-estar espiritual em pessoas idosas institucionalizadas. Este é um domínio do bem-estar que se tem mostrado relevante para a qualidade de vida, saúde física e mental. Dada a sua importância, faltava um instrumento validado para a população idosa, especialmente a institucionalizada, onde, de certo, o significado e sentido da vida será posto à prova todos os dias.

Na secção Artigos de Revisão, Espírito-Santo e Daniel vêm terminar um percurso relativo à importância do cálculo e apresentação dos tamanhos do efeito a par com os testes estatísticos. Em 2015, as autoras (Espirito-Santo \& Daniel, 2015) tinham revisto os tamanhos do efeito para as diferenças de médias entre dois grupos. Em 2017, tinham exposto os pressupostos teóricos, fórmulas e diretrizes para a apresentação dos tamanhos do efeito para as correlações e outras medidas de associação (Espirito-Santo \& Daniel, 2017). No entanto, faltava apresentar os tamanhos do efeito para as análises da variância explicada. Desta feita, no artigo "Calcular e apresentar tamanhos do efeito em trabalhos científicos (3): Guia para reportar os tamanhos do efeito para análises de regressão e ANOVAs", as autoras reveem os argumentos teóricos, fórmulas de cálculo e interpretação dos tamanhos do efeito mais comuns para os modelos lineares gerais (análises de regressão e ANOVA). À semelhança dos artigos anteriores, as autoras suplementam o artigo com uma folha de cálculo para auxiliar os interessados.

Terminamos este editorial agradecendo a todo(a)s o(a)s revisore(a)s e autore(a)s o contributo e a confiança que deposita(ra)m na RPICS. Desejamos a todos um bom ano. 
In 2018, the editors of the Portuguese Journal of Behavioral and Social Research (PJBSR) continue to favor the publication of original articles of investigation and revision in the areas of social and behavioral sciences. The PJBSR continues to promote thinking, questioning the changes in society, their realities, and rethinking their problems, encouraging a reflection among their readers.

The number 1 of the fourth volume of the PJBSR adds four original articles and one review article. Although this issue of the PJBSR addresses different contents, there is evidence of a focus on the study of positive psychological variables and their relation to human well-being, whether it is operationalized as physical or mental health, studied in the context of institutionalization or in the context of the work, evaluated at the level of the subjective perception of wellbeing or the level of the conception of death with dignity.

Therefore, the first article - "Self-compassion, wellbeing, and health in advanced age" (Parente, Cunha, Galhardo, and Couto) - confirms the evidence that the status of physical and mental health in old age is associated with compassion and with subjective well-being. These positive factors will be critical elements for a more soothing perception of aging, and for the adoption of an adaptive style of coping when facing the difficulties in old age. The evidence that older people living in their own homes are more compassionate than the older ones living in the institutionalized context reiterates the importance of adopting programs and strategies at the level of self-compassion that promote greater satisfaction with life, better mental and physical health, especially among institutionalized elderly.

The second article - "Perception of Brazilians on death with dignity" (Melo, Bezerra, and Lima) - raised an interesting question: what is the conception of Brazilians about what is to die with dignity and what are the distinctions in sociodemographic diversities? The results allow us to reflect on the procedures to be developed in the care of patients in the process of dying and of their relatives and showing that the concern goes beyond the medical community and is widespread in society. In fact, what is at stake is the reflection on death and its removal from the hospital context.

Another area that deserves reflection concerns the wellbeing of those with an active profession, namely university professors. The authors of the study "Psychosocial risks evaluation factors: Study with higher education teachers" (Borges, Santos, Saraiva, and Pocinho) showed that university professors live in situations of psychosocial risk, especially public-school teachers, female teachers, and the oldest ones. Their findings stimulated the authors to emphasize the importance of primary, secondary, and tertiary interventions.
This round of original articles ends as it began, refocusing on well-being in old age, especially among institutionalized older adults. In the study "Validation of the Portuguese version of the Spiritual Well-Being Questionnaire for the institutionalized elderly population", Neves, Garcia, Espírito-Santo, and Lemos sought to contribute to the analysis of the psychometric properties and validation of a tool for measuring spiritual well-being in institutionalized older people. This is a domain of well-being that has shown to be relevant to the quality of life, physical, and mental health. Given its importance, a validated instrument for the older population was lacking, especially the institutionalized, where, of course, the meaning of life is put to the test every day.

In the Review Articles section, Espírito Santo and Daniel have concluded the journey regarding the importance of calculating and presenting the effect sizes along with the statistical tests. By 2015, the authors (Espirito-Santo \& Daniel, 2015) had reviewed the effect sizes for the mean differences between two groups. By 2017, they had set forth the theoretical assumptions, formulas, and guidelines for the presentation of correlations and other measures of association effect sizes (Espirito-Santo \& Daniel, 2017). However, the effect sizes for the analyzes of the explained variance were lacking. Hence, in the article "Calculating and reporting effect sizes on scientific papers (3): Guide to report regression models and ANOVA effect sizes", the authors review theoretical arguments, formulas for calculation and interpretation of most common effect sizes for general linear models (regression analysis and ANOVA). Like the previous articles, the authors supplement the manuscript with a spreadsheet to assist those interested.

We end this editorial by thanking all reviewers and authors for the contribution and trust they place on the PJBSR. We wish everyone a good year.

\section{REFERÊNCIAS}

Espirito-Santo, H. e Daniel, F. B. (2015). Calcular e apresentar tamanhos do efeito em trabalhos científicos (1): As limitações do $p<0,05$ na análise de diferenças de médias de dois grupos. Revista Portuguesa de Investigação Comportamental e Social, 1(1), 3-16. doi: 10.7342/ismt.rpics.2015.1.1.14

Espirito-Santo, H. e Daniel, F. (2017). Calcular e apresentar tamanhos do efeito em trabalhos científicos (2): Guia para reportar a força das relações. Revista Portuguesa de Investigação Comportamental e Social, 3(1), 53-64. doi:10.7342/ismt.rpics.2017.3.1.48 